biotics appear to stop bacterial deconjugation of bile salts not only in the small intestine but also in the colon.

\section{Conclusion}

The ${ }^{14} \mathrm{C}$-glycocholic acid breath test is a useful and simple screening test for the detection of bacterial deconjugation of bile salts. This may be of value not only in the diagnosis of bacterial overgrowth syndromes but also in the evaluation of cholangitis. Facilities for elaborate anaerabic bacterial culture are not generally available; however, this test may be performed in any hospital with liquid scintillation counting equipment. It may be used on an outpatient basis and is fairly inexpensive (total cost about £5 per patient).

\section{References}

Badley, B. W. D., Murphy, G. M., and Bouchier, I. A. D. (1969). Lancet, 2,

Cerlek, S., Mustrovic, F., and Govorcin, B. (1965). Medicinski Pregled, 18,

247.
Fromm, H., and Hofmann, A. F. (1971). Lancet, 2, 621

Hamilton, J. D. et al. (1972).Quarterly fournal of Medicine, 39, 265.

Hofmann, A. F., and Fromm, H. (1971). New England fournal of Medicine, 279, 686.

Horchner, P. et al. (1972). Folia Medica Neerlandica, 15, 186.

James, O., Agnew, J. E., Lydford, R., and Bouchier, I. A. D. (1972). Gut $13,845$.

Kalser, M. H. et al. (1966). New England fournal of Medicine, 274, 500, 558. Lal, D. Gorback, S. L and Levitan, R (1972). Gastroenterology, 62, 275 Martini, G. A., Phear, E. A., Ruebner, B., and Sherlock, S. (1957). Clinical Science, 16, 35.

Parkin, D. M. et al. (1972). Lancet, 2, 777.

Parkin, D. M. et al. (1972). Lancet, 2, 777.

Sherr, H. P. et al. (1971). New England fournal of Medicine, 279, 656.

\title{
Respiratory Disease in Young Adults: Influence of Early Childhood Lower Respiratory Tract Illness, Social Class, Air Pollution, and Smoking
}

\author{
J. R. T. COLLEY， J. W. B. DOUGLAS， D. D. REID
}

British Medical fournal, 1973, 3, 195-198

\section{Summary}

The prevalence of cough during the day or night in winter has been studied in 3,899 20-year-olds. These were members of a cohort born in England, Scotland, and Wales in the last week of March 1946. The prevalence of cough and current smoking habits have been related to events recorded during infancy and childhood-that is, exposure to air pollution, social class of father, and lower respiratory tract illness under 2 years of age. At age 20 , of these factors cigarette smoking was found to have the greatest effect on symptom prevalence, followed by a history of a lower respiratory tract illness under 2 years of age. Social class and air pollution had little effect.

\section{Introduction}

There is still doubt about the long-term consequence of early childhood chest illness. Paediatric opinion has tended to regard the improvement in respiratory experience that occurs as children grow up as indicating permanent cure. On this view, what happens later in adult life-for example, the development of symptoms and signs of chronic bronchitis-would be quite unrelated to childhood experience. There is evidence from a number of epidemiological studies suggesting that this view may not be true. From these studies it seems that childhood experience is relevant to respiratory disease in early adult life (Colley, 1971).

We present the respiratory findings in a birth cohort followed until the age of 20 years. We have studied the relations of social class, lower respiratory tract illness under 2 years of age, air

London School of Hygiene and Tropical Medicine, London WC1E 7HT

J. R. T. COLLEY, M.D., B.SC., Senior Lecturer in Epidemiology

D. D. REID, M.D., F.R.C.P., Professor of Epidemiology

M.R.C. Unit for the Study of Environmental Factors in Mental and Physical Illness, London School of Economics, London WC2 J. W. B. DOUGLAS, B.M., B.Sc., Director pollution, and smoking to the frequency of respiratory symptoms at the age of 20 years.

\section{Methods}

The material forming the basis of this paper is part of that collected during the follow-up of the cohort of children who were all born in England, Wales, and Scotland in the last week of March 1946. The objectives of the original study and the sampling methods used are described elsewhere (Douglas and Blomfield 1958; Douglas 1964; Douglas et al., 1968).

The original population consisted of 13,687 infants born alive in the last week of March 1946. The sample so obtained was not the entire births in that period. This was owing to the nonco-operation of a few maternal and child welfare authorities and to late registration of some births. There is, however, no reason to assume that any serious biases have been introduced into the sample by these losses. As only limited funds were initially available for the study twins and illegitimate children were excluded from the sample of 13,687 infants. This left a total of 12,468 from which the follow-up sample was drawn. All births to non-manual workers and all births to agricultural workers were included but only one out of every four births to manual workers. The final sample size was 5,362 of whom 4,701 were living in Great Britain in 1964.

In 1946 there was no intention to follow these infants for more than a few years. In the event most have been followed for more than 20 years. During the follow-up period information has been collected at different times on social factors, environmental exposure, illness, educational attainment, and other aspects of the development of these children. The following specific items were studied.

Lower Respiratory Tract Infection Under Two Years of Age.This history was obtained at interview by health visitors from the parents when the child was 2 years old. The question asked was, "Has this baby ever had a lower respiratory infectionthat is, bronchitis, bronchopneumonia, or pneumonia?"

Social Class Classification.-This is based on the 1957 occupation of the father of the survey child, on the education of both parents, and the occupation of both grandfathers. Where the 1957 occupation is not known the 1946 occupation has been used. Four social class groups are used: (1) upper middle class, (2) lower middle class, (3) upper manual working 
class, and (4) lower manual working class (see Appendix 1 for details).

Air Pollution Index.-The level of exposure to air pollution has been estimated from domestic coal consumption for the towns and rural areas where these children resided. For each child estimates of exposure are available for seven occasions between 1948 and 1957. A simple four-point scale of pollution has been used (Douglas and Waller, 1966)-1, very low pollution; 2, low pollution; 3, moderate pollution; and 4, high pollution. For each child the air pollution grades for these seven occasions have been summed to provide an individual exposure score. For example, a child who on each of the seven occasions was exposed to very low pollution would have an exposure score of 7 , while a child who on each occasion has exposure to high pollution would score 28 . Some children did not have complete data on their pollution exposure and these children have been kept as a separate group. In the tables that follow children have been categorized into five air pollution exposure groups: those with scores of 7-10, 11-17, 18-24, 25-28, and the group with incomplete data.

Respiratory Symptoms and Smoking Habits when 20 Years Old.-In 1966 a questionnaire was sent to all surviving members of the final 1946 birth cohort. The questionnaire included questions on respiratory symptoms and smoking habit (see Appendix 2). The symptomatic questions were those approved by the Medical Research Council's Committee on the Aetiology of Chronic Bronchitis (1960). On the basis of the questions on smoking habit three categories have been defined: nonsmokers-that is, those who have never smoked-present smokers, and ex-smokers. Those who reported occasional cigarette smoking - that is, less than one cigarette a day-were classified as non-smokers. There is an additional category for those who did not record their smoking habits.

\section{Results}

It is inevitable in a follow-up study over a period as long as 20 years that substantial losses will occur from the population. Out of the final sample of 5,362 persons 4,701 were living in Great Britain at 18 years.* Of these, $802(17 \%)$ were not included in the 20-year study either because they refused or because they were untraced, leaving 3,899 for study. Apart from the effects in reducing the numbers for study at the age of 20 , a non-response rate of this size may introduce biases in the comparisons reported in this paper. A comparison was made between the responders and non-responders to see if there were any important differences in their history of respiratory illnesses, exposure to air pollution, and their social class.

The proportion of non-responders with a history of lower respiratory tract illness under the age of 2 years was similar to the proportion found in the responders. Also the social class distribution was similar in the non-responders and responders. The non-responders were, however, under-represented in the low pollution group (7-10) and over-represented in the high pollution group (25-28).

The prevalence of respiratory symptoms by smoking habit at the age of 20 years, by sex, is given in table I. For all symptoms smokers have higher reported prevalence than non-smokers. The prevalence rates for ex-smokers and those who did not record their smoking habits are based, particularly among the women, on rather small numbers. The male prevalence rates for these two groups usually lie between those for the smokers and non-smokers. In the present smoker, and non-smoker groups there is no consistent male:female difference in prevalence. In view of this, and as the total numbers of males and females are similar, the data from the two sexes have been combined in the tables that follow where the prevalence of cough during the day or at night in the winter (chronic cough in the winter, question $1(b)$, Appendix 2) is used as the index of respiratory disability.

The prevalence rates of chronic cough by smoking habit in the four social clässes, set out in table II, show a consistently higher prevalence among the present smokers than the nonsmokers. Overall prevalence in smokers is 2.5 times that of non-smokers. In contrast the differences in prevalence between social classes are much smaller. Among non-smokers there is a trend in prevalence with social class; rates are lowest in the upper middle class and rise to a maximum in the lower manual class. In the present smokers there is also a trend, though it is not wholly consistent. In both cases, however, application of the modified $\chi^{2}$ test for trend (Armitage, 1971) shows that this trend could have arisen by chance.

The prevalence of chronic cough in winter by smoking habit and air pollution index is given in table III. In present smokers chronic cough prevalence is at a maximum in the two groups exposed to the highest air pollution and lowest in the lowest pollution group. Non-smokers do not have the same prevalence pattern; the rates rise in step with air pollution except for those exposed to the highest levels of air pollution.

Linking the information on lower respiratory tract illness under 2 years of age, smoking, and respiratory symptoms at 20 (table IV) shows that those with a history of lower respiratory tract illness have a higher prevalence of cough during the day or at night in the winter than those without such a history. In both smoking groups a history of chest illness is associated with an increased prevalence of cough.

Data from previous tables are combined in table $V$ to enable assessment of the interdependence of all the factors included in the survey. It is clear from the preceding tables that, because the rates are sometimes based on small numbers and the factors are themselves interrelated, it is difficult to assess the presumptive influence that each has on the prevalence of respiratory disease. There are, too, hints that there is an interaction in that air pollution differences, for example, are apparent only among social classes 3 and 4 . In an attempt to clarify these issues logistic and non-logistic or linear models were fitted in turn to the data. In fact, the goodness of fit of these two models was not significantly different ( $x^{2}$ of 8.11 and 7.41 on 11 degrees of freedom respectively). In other words, there was no suggestion that a multiplicative model was more appropriate. An examination of the residuals from the additive model did not indicate any gross or statistically significant departure from the expected values for any cell of the table, as might have been the case if interactions had been present. But using the additive model it was possible to determine the presumptive independent effects of each factor after adjusting for simultaneous variation in the other factors and to assess their statistical significance.

The results are summarized in table VI. Clearly smoking has the largest presumptive effect in terms of the difference in the standardized prevalence rates for non-smokers and smokers after adjusting for the other variables-that is, $7 \cdot 15 \%$ and $14.56 \%$ respectively. Early childhood chest illness has a smaller effect-that is, $9.28 \%$ and $12.43 \%$ for those without and with such a history-while social class and air pollution exert only a small and statistically non-significant influence when the other variables have been allowed for.

\section{Discussion}

Some caution is needed in interpreting the findings from this study. As already noted the non-responders had an air pollution exposure that was not identical with that of the responders. It is not possible to assess whether this difference and the exclusions in some tables of persons with absent data have materially affected the prevalence rates. There is, however, a coherence and a consistency in the patients of prevalence observed that give confidence in the interpretation of ihe results.

* The position at 18 years has been taken as being more accurately determined than at 20 . It is a slight over-estimate of the numbers in this country which on a recent count (at age 26 ) were 4,350 and 12 who may have emigrated. 
TABLE I-Prevalence (\%) of Respiratory Symptoms by Sex and Smoking Habit

\begin{tabular}{|c|c|c|c|c|c|c|c|c|c|c|c|c|c|c|c|c|c|c|c|}
\hline \multicolumn{4}{|c|}{ History of Cigarette Smoking } & \multicolumn{2}{|c|}{ Population* } & \multicolumn{2}{|c|}{$\begin{array}{l}\text { Winter } \\
\text { Morning } \\
\text { Cough } \\
\text { Q. } 1(a) \dagger\end{array}$} & \multicolumn{2}{|c|}{$\begin{array}{l}\text { Cough Day } \\
\text { or Night } \\
\text { in Winter } \\
\text { Q. } 1(b) \dagger\end{array}$} & \multicolumn{2}{|c|}{$\begin{array}{l}\text { Cough } 3 \\
\text { Months in } \\
\text { Winter } \\
\text { Q. } 1(c) \dagger\end{array}$} & \multicolumn{2}{|c|}{$\begin{array}{l}\text { Winter } \\
\text { Morning } \\
\text { Phlegm } \\
\text { Q. 2(a)† }\end{array}$} & \multicolumn{2}{|c|}{$\begin{array}{l}\text { Phlegm Day } \\
\text { or Night } \\
\text { in Winter } \\
\text { Q. } 2(b) \dagger\end{array}$} & \multicolumn{2}{|c|}{$\begin{array}{l}\text { Phlegm } 3 \\
\text { Months in } \\
\text { Winter } \\
\text { Q. } 2(c) \dagger\end{array}$} & \multicolumn{2}{|c|}{$\begin{array}{c}\text { Persistent } \\
\text { Cough and } \\
\text { Phlegm } \\
\text { Q. } 1(c)+2(c) \dagger\end{array}$} \\
\hline & & & & M. & F. & M. & F. & M. & F. & M. & F. & M. & F. & M. & F. & M. & F. & M. & F. \\
\hline $\begin{array}{l}\text { Never smoked cigarettes } \\
\text { Ex-smokers of cigarettes } \\
\text { Present smoker of cigarettes } \\
\text { No data on cigarette smoking }\end{array}$ & $\begin{array}{l}\cdots \\
\cdots\end{array}$ & $\begin{array}{l}\ldots \\
\because \\
\cdots\end{array}$ & $\begin{array}{l}. . \\
\ldots \\
\ldots\end{array}$ & $\begin{array}{r}802 \\
101 \\
1,009 \\
92\end{array}$ & $\begin{array}{r}1,093 \\
57 \\
678 \\
48\end{array}$ & $\begin{array}{r}1 \cdot 6 \\
3 \cdot 0 \\
13 \cdot 0 \\
8 \cdot 7\end{array}$ & $\begin{array}{r}4.0 \\
1.8 \\
13.2 \\
11.8\end{array}$ & $\begin{array}{r}5 \cdot 2 \\
7 \cdot 1 \\
13 \cdot 9 \\
9 \cdot 1\end{array}$ & $\begin{array}{r}6 \cdot 5 \\
10 \cdot 5 \\
16 \cdot 0 \\
18 \cdot 8\end{array}$ & $\begin{array}{l}1 \cdot 5 \\
3 \cdot 0 \\
8 \cdot 1 \\
4 \cdot 5\end{array}$ & $\begin{array}{l}3 \cdot 2 \\
1 \cdot 8 \\
7 \cdot 5 \\
0 \cdot 0\end{array}$ & $\begin{array}{r}4 \cdot 8 \\
11 \cdot 0 \\
14 \cdot 1 \\
0 \cdot 0\end{array}$ & $\begin{array}{r}5.2 \\
1.9 \\
11.9 \\
6.7\end{array}$ & $\begin{array}{r}6 \cdot 4 \\
10 \cdot 2 \\
11 \cdot 6 \\
4 \cdot 8\end{array}$ & $\begin{array}{r}3.9 \\
9.1 \\
11 \cdot 2 \\
0.0\end{array}$ & $\begin{array}{l}3.7 \\
6.0 \\
8.3 \\
4.8\end{array}$ & $\begin{array}{l}3.2 \\
0.0 \\
5.5 \\
0.0\end{array}$ & $\begin{array}{l}0.9 \\
2.0 \\
4.9 \\
4.8\end{array}$ & $\begin{array}{l}1.9 \\
0.0 \\
3.5 \\
0.0\end{array}$ \\
\hline All & $\ldots$ & $\ldots$ & $\ldots$ & 2,022 & 1,876 & $7 \cdot 7$ & $7 \cdot 4$ & $9 \cdot 8$ & $10 \cdot 2$ & $5 \cdot 0$ & $4 \cdot 7$ & 9.9 & $7 \cdot 6$ & $9 \cdot 3$ & 6.7 & $6 \cdot 2$ & 3.9 & 3.0 & $2 \cdot 4$ \\
\hline
\end{tabular}

*One subject with sex code missing.

†See Appendix 2.

TABLE II-Prevalence (\%) for Cough Day or Night in Both Sexes in Winter by History of Cigarette Smoking and Social Class of Father in 1957.* Figures in parentheses are population

\begin{tabular}{|c|c|c|c|c|c|c|c|c|c|c|c|c|c|c|}
\hline \multirow{2}{*}{\multicolumn{2}{|c|}{ History of Cigarette Smoking }} & & \multicolumn{8}{|c|}{ Social Class } & & & & \\
\hline & & & \multicolumn{2}{|c|}{$\begin{array}{l}\text { Upper Middle } \\
\text { (1) }\end{array}$} & \multicolumn{2}{|c|}{$\begin{array}{l}\text { Lower Middle } \\
\text { (2) }\end{array}$} & \multicolumn{2}{|c|}{$\begin{array}{l}\text { Upper Middle } \\
\text { (3) }\end{array}$} & \multicolumn{2}{|c|}{$\begin{array}{c}\text { Lower Manual } \\
\text { (4) }\end{array}$} & \multicolumn{2}{|c|}{ Incomplete Data } & \multicolumn{2}{|c|}{ All } \\
\hline $\begin{array}{l}\text { Never smoked cigarettes } \\
\text { Present smoker of cigarettes }\end{array}$ & $\begin{array}{ll}. & \\
. & \end{array}$ & $\because$ & $\begin{array}{r}5 \cdot 4 \\
12 \cdot 7\end{array}$ & $\begin{array}{l}(276) \\
(165)\end{array}$ & $\begin{array}{r}5 \cdot 5 \\
13 \cdot 5\end{array}$ & $\begin{array}{l}(638) \\
(488)\end{array}$ & $\begin{array}{r}5 \cdot 8 \\
12 \cdot 1\end{array}$ & $\begin{array}{l}(294) \\
(298)\end{array}$ & $\begin{array}{r}6.8 \\
16.9\end{array}$ & $\begin{array}{l}(651) \\
(692)\end{array}$ & $\begin{array}{r}3 \cdot 2 \\
25 \cdot 0\end{array}$ & $\begin{array}{l}(31) \\
(20)\end{array}$ & $\begin{array}{r}5 \cdot 9 \\
14 \cdot 7\end{array}$ & $\begin{array}{l}(1,890) \\
(1,663)\end{array}$ \\
\hline
\end{tabular}

*Excluding 156 ex-smokers and 38 with smoking history unknown, and 152 with history of cough day or night not known.

TABLE III-Prevalence (\%) for Cough Day or Night in Both Sexes in Winter by History of Cigarette Smoking and Air Pollution Index.* Figures in parentheses are population

\begin{tabular}{|c|c|c|c|c|c|c|c|c|c|c|c|c|c|c|}
\hline \multirow{2}{*}{\multicolumn{3}{|c|}{ History of Cigarette Smoking }} & \multicolumn{8}{|c|}{ Air Pollution Index } & & & & \\
\hline & & & \multicolumn{2}{|c|}{$7-10$} & \multicolumn{2}{|c|}{$11-17$} & \multicolumn{2}{|c|}{$18-24$} & \multicolumn{2}{|c|}{$25-28$} & \multicolumn{2}{|c|}{ Incomplete Data } & \multicolumn{2}{|c|}{ All } \\
\hline $\begin{array}{l}\text { Never smoked cigarettes } \\
\text { Present smoker of cigarettes }\end{array}$ & 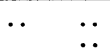 & 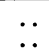 & $\begin{array}{r}4 \cdot 5 \\
12 \cdot 7\end{array}$ & $\begin{array}{l}(332) \\
(259)\end{array}$ & $\begin{array}{r}6 \cdot 9 \\
13 \cdot 2\end{array}$ & $\begin{array}{l}(613) \\
(478)\end{array}$ & $\begin{array}{r}7 \cdot 4 \\
16.9\end{array}$ & $\begin{array}{l}(435) \\
(419)\end{array}$ & $\begin{array}{r}4 \cdot 4 \\
16.7\end{array}$ & $\begin{array}{l}(295) \\
(300)\end{array}$ & $\begin{array}{r}4 \cdot 7 \\
13 \cdot 5\end{array}$ & $\begin{array}{l}(215) \\
(207)\end{array}$ & $\begin{array}{r}5.9 \\
14.7\end{array}$ & $\begin{array}{l}(1,890) \\
(1,663)\end{array}$ \\
\hline
\end{tabular}

Excluding 156 ex-smokers and 38 with smoking history unknown, and 152 with history of cough day or night not known.

This longitudinal study has the unique advantage that data on illness in early childhood, exposure to air pollution, and social class background derive from records made contemporaneously. The estimates of the presumptive effects of these factors are thus not biased by fallible memories coloured by the current experience of respiratory disease in early adult life. Moreover, data on smoking are related to the time of survey.

The finding that cigarette smoking in these young adults has a major effect on respiratory symptoms causes no surprise. Holland and Elliott (1968) found in their study of a large group
TABLE IV-Prevalence (\%) for Cough Day or Night in Both Sexes in Winter by Cigarette Smoking and Chest Illness Under 2 Years of Age.* Figures in parentheses are population

\begin{tabular}{|c|c|c|}
\hline \multirow{2}{*}{ Chest Illness Under 2 Years of Age } & \multicolumn{2}{|c|}{ Cigarette Smoking } \\
\hline & Never Smoked & Present Smo ker \\
\hline $\begin{array}{l}\text { No chest illness } \\
\text { One or more chest illnesses }\end{array}$ & $\begin{array}{r}(1,361) \\
(397)\end{array}$ & $\begin{array}{ll}13.7 & (1,141) \\
16.5 & (423)\end{array}$ \\
\hline
\end{tabular}

*Excluding 577 persons-that is, ex-smokers and those whose history of ci gar ette smoking and of chest illness under 2 years of age and history of cough day and night s not known.

TABLE v-Prevalence (\%) of Cough Day or Night in Both Sexes in Winter by Air Pollution Index, Social Class, Cigarette Smoking, and Chest Illness Under 2 Years of Age.* Figures in parentheses are population

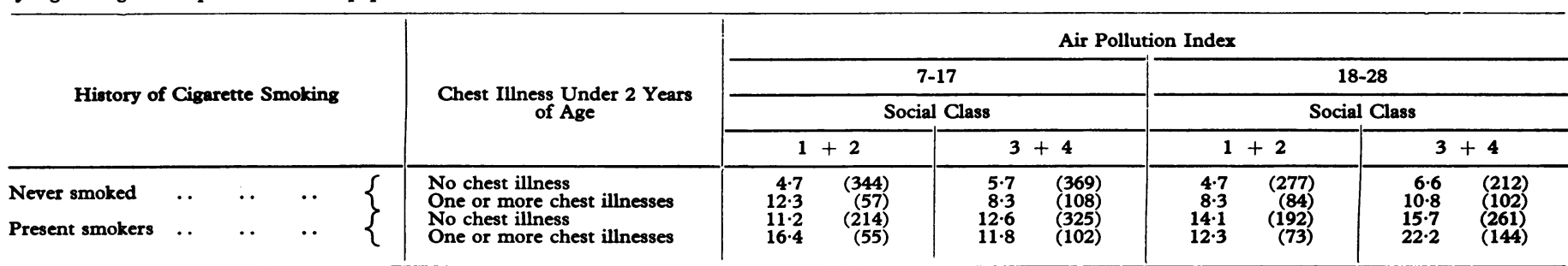

Excluding 980 persons-that is, ex-smokers and those whose history of cigarette smoking, social class, air pollution index, chest illness under 2 years of age, and history of cough day or night not known.

TABLE vI-Crude and Standardized Prevalence Rates (\%) for Cough Day or Night in Winter, for the Two Levels of Each Factor with Estimates of Their Effect

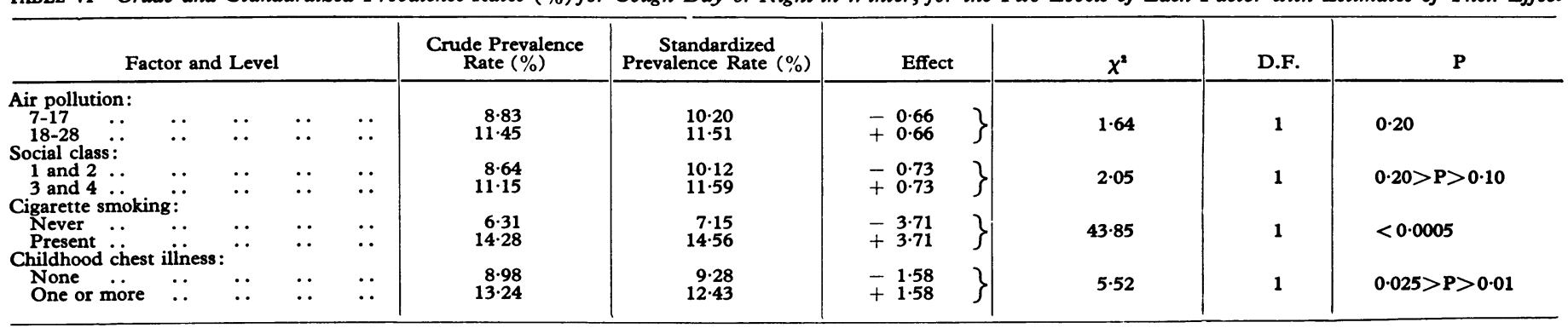


of secondary schoolchildren in south-east England that those who admitted to smoking had higher respiratory symptom prevalence rates than non-smokers.

This study provides confirmation of the suspected association of lower respiratory tract illness in childhood and early adult life. Moreover, in the circumstances of the U.K., early childhood chest illness contributes more than social class or air pollution to the differences in the frequency of respiratory disability in early adult life. When allowance is made for the effects of other variables (table VI) the effects of social class and air pollution are, at this age, small.

These findings in young adults should be contrasted with those found earlier in life. Douglas and Waller (1966) described the relations between air pollution, social class, and the incidence of lower respiratory tract illness in this cohort under the age of 2 years. At this age air pollution had a major effect on the incidence of two or more attacks of lower respiratory tract infections, for there was a threefold difference in the incidence of these infections between children exposed to the lowest air pollution levels and those exposed to the highest. The social class effect was smaller, there being a twofold difference in incidence between middle class and manual working class children. Colley and Reid (1970) found in their study of a large sample of older children-that is, 6-10-year-olds-that social class had a larger effect than had air pollution. These studies give support to the view that exposure to air pollution and to adverse social class conditions influence the risk of having a lower respiratory tract infection in early childhood. At the age of 20, however, when smoking has a dominant effect, these factors do not appear to be important.

\section{Conclusions}

Though a life-long susceptibility to respiratory disease may be a genetically determined defect, it appears from this and other studies that environmental factors materially affect the evolution of potentially serious disability in the first 20 years of life. Exposure to air pollution and adverse social circumstances are important in respiratory illness in childhood but smoking becomes the dominant factor by the age of 20 years. Since little can be done to remedy the deficiencies of the past, the most important immediately effective action that can be taken among young adults is to discourage smoking before permanent damage is done. Of all the groups covered in this study the risk of respiratory disability is greatest in those who were exposed to high levels of atmospheric pollution and poor social class conditions and who had one or more chest illnesses in early childhood. For them, advice on smoking is likely to be of special importance.
We would especially like to thank Mrs. B. Hunt who carried out the analysis of the data.

\section{Appendix I}

\section{SOCIAL CLASS CLASSIFICATION}

The classification is based, for the most part, on the 1957 occupation of the father of the survey child; where this is not known, on the 1946 occupation. 1. Upper Middle Clas

The father is a non-manual worker, and

(a) both parents went to secondary school and were brought up in middle class families, or

(b) both parents went to secondary school and one parent was brought up in a middle class family, or

(c) both parents were brought up in middle class families and one parent went to secondary school.

2. Lower Middle Class

The rest of the non-manual workers' families.

3. Upper Manual Working Class

The father is a manual worker, and

either the father or mother or both of them had a secondary school education, and/or one or both of them were brought up in a middle education, and

4. Lower Manual Working Class

The father is a manual worker, and

both the father and the mother had elementary schooling only, and both the father and the mother were brought up in manual working class families.

\section{Appendix 2}

1. (a) Do you usually cough first thing in the morning in the winter ? (b) Do you usually cough during the day or at night in the winter? If "Yes" to either question $1(a)$ or $(b)$

(c) Do you cough like this on most days for as much as three months each winter?

2. (a) Do you usually bring up any phlegm (spit from the chest) first thing in the morning in the winter?

(b) Do you usually bring up any phlegm (spit from the chest) during the day or at night in the winter?

If "Yes" to either question $2(a)$ or $(b)$

(c) Do you bring up phlegm (spit from the chest) on most days for as much as three months each winter?

3. Do you smoke CIGARETTES now?

(a) Yes, regularly

(b) Occasionally (usually less than one a day)

(c) No

4. If you do NOT smoke cigarettes now, did you EVER smoke them?

\section{References}

Armitage, P. (1971). Statistical Methods in Medical Research. Oxford, Blackweil Scientific.

Colley, J. R. T. (1971). British Medical Bulletin, 27, 9

Colley, J. R. T., Reid, D. D. (1970). British Medical fournal, 2, 213.

Douglas, J. W. B. (1964). The Home and the School. Aldershot, MacGibbon and Kee.

Douglas, J. W. B., and Blomfield, J. M. (1958). Children under Five. London, Allen and Unwin.

Douglas, J. W. B., Ross, J. M., and Simpson, H. R. (1968). All Our Future. London, Peter Davis.

Douglas, J. W. B., and Waller, R. E. (1966). British fournal of Preventive and Social Medicine, 20, 1.

Holland, W. W., and Elliott, A. (1968). Lancet, 1, 41.

M.R.C. Committee on the Aetiology of Chronic Bronchitis (1960). British Medical fournal, 2, 1665. 